\title{
Improvement of the procedure for assessing the personnel of the agricultural organization
}

\author{
Alsou Zakirova ${ }^{1}$, Guzaliya Klychova ${ }^{1}$, Olga Doroshina $^{2}$, Ilnur Safiullin ${ }^{1}$ Regina Nurieva ${ }^{1}$, \\ and Zariya Zalilova ${ }^{3, *}$ \\ ${ }^{1}$ Kazan State Agrarian University, 420015 Kazan, Russia \\ ${ }^{2}$ University of Management "TISBI", Department of Accounting and Taxation, 420012 Kazan, Russia \\ ${ }^{3}$ Bashkir State Agrarian University, 450001, Ufa, Russia
}

\begin{abstract}
Assessment, as an integral part of the management process, it is the most effective system for the certification of the organization personnel. This procedure helps in determining the qualification and level of knowledge of employees, assess their abilities, moral and business skills. Each employee in the performance of his duties must use rational methods and modern technical means to ensure effective organization of production. The purpose of the article is substantiation of theoretical principles and development of practical recommendations for improving the procedure for assessing an agricultural organization personnel. The objectives of the research are: study of theoretical aspects and methodological tools, identification of the stages, and development of documentary support for the personnel assessment system. Such methods as the analysis of scientific and theoretical sources, the systematic approach, the method of comparative analysis, and generalization were used in the process of writing the article. The paper presents recommendations for the development of an effective certification system and its documentary support in agricultural organizations perfectly meeting the goals of the organization under study as well as its needs and the organizational culture developed in it.
\end{abstract}

\section{Introduction}

Issues related to the efficient use of human resources are becoming increasingly important in the conditions of uncertainty and recession. The management of organizations is focused on maintaining efficient and competitive activity. Herewith,personnel is a resource, which ensures its effective functioning. The main methods and criteria for assessing the«quality» of human resources, will change in accordance with the peculiarity and working conditions modification.

In addition to a good level of professional knowledge, which isso important in current conditions, such human qualities as the learning ability, communication skills, generation of new ideas and their implementation are particularly relevant. In this respect, issues of personnel assessment are becoming increasingly important.

\footnotetext{
* Corresponding author : zakirovaar@mail.ru
} 
Assessment allows evaluating of business, personal and professional performance of employees and contributes to the implementation of personnel management in such areas as personnel planning, adaptation, laborincentives, development of skills, etc.

The influence of modern financial, economic, legal, social and informational conditions on the functioning of most organizations determines the need in rationalizing work with personnel in order to improve the professionalism of employees, strengthen the requirements for their business skills and labor efficiency [1,2].

Correct selection, placement and use of personnel, considering the qualification, level of training, work experience, rational division and cooperation of the specialists' efforts, timely encouragement and recovery based on the results of their activities form the basis of this work [3]. Personnel assessment is an essential tool for the improvement of personneladministration and in general the personnel management system improvement.

Personnel assessment is a set of personnel activities, which allow evaluating of the personal qualities, potential and level of human labor compliance with the existing requirements to work performed $[4,5]$. The main purpose of assessment is to identify the reserves for improving the efficiency of employees, to monitor professional growth and qualification of specialists. In the event an employee is recognized as inappropriate to his position, it is necessary to make a decision on his retraining or transfer to another position.

\section{Materials and Methods}

Hiring of employees is a part of the investment process and involves careful selection and hiring procedure, adaptation, training and motivation, which means investing in personnel $[6,7]$.

The production efficiency increases as a result of the assessment. In particular, the placement of staff is improved as a result of the selection of the most suitable candidates for a particular position, as well as the use of personnel; the directions for the workers retraining is determined; due to the close relationship between the results of labor and its payment, the labor activity is intensified; the ways and forms of managers' activity is also improved.

Personnel assessment allows establishing the degree of employees motivation (including career growth); determine the directions for the strategic development at the enterprise; increase workforcediscipline; establish compliance of the enterprise with the corporate culture $[8,9]$.

The main issues solved in the process of personnel assessment include:

- the ability to manage staff and evaluate its role and place in the organizational structure of the enterprise, depending on its achievements [10];

- the ability to determine the size of remuneration based on the assessment of the personnel performance results;

- the possibility of professional growth of employees as a result of the effective use of incentives and motivation forms for labor;

- the possibility of rational use of human resources when hiring, transfer and making a decision on leaving;

- the possibility of labor motivation to an effective activity implementation, the purpose of which is the career promotion;

- the possibility of establishing feedback with the employee;

- the ability to meet the needs of the employee in the personal labor assessment.

As you can see, the main objectives of the assessment include the issues of improving the selection, advanced training, management of wage issues, incentives for the professional career promotion of the personnel [11, 12]. 
The key principles of an effective personnel assessment system include: focus on improving performance, thorough preparation, confidentiality, standard and reliableassessment criteria; balanced approach in combination of encouragement and criticism, accuracy of the applied methods $[13,14]$.

Methodological tools usedin the process of the assessment preparation and conducting are very important. In particular, one can apply methods to evaluate various indicators, their availability or absence, theirintensity in this or that employee. These include:

- Monitoring the process of key management communications (meetings, audits, consultations). It is a method involving collection of sociological information on the object under study and based on direct perception and direct recording of events that are significant from the point of view of research objectives[15, 16];

- Analysis of documents - a method involving systematic analysis of documents in order to obtain information necessary for conducting research [17];

- Survey is a method of collecting social information on the object of research during direct (interview) or indirect (questioning) social and psychological communication between the interviewer and the respondent (the inquireable) by registering the respondents' answers to the questions asked;

- Expert survey is a type of survey, in which respondents are experts - specialists in a specific field of activity. A distinctive feature of this method is that it involves the competent participation of experts in analyzing and solving research problems;

- Social experiment is a method of obtaining information on changes in the performance indicators of an attestation object when exposed to specified and controlled variables (factors) [18];

- Assessment of key personnel - a method of personnel certification based on modeling key points of activity, in order to identify the professionally significant qualities of the staff;

- A questionnaireof heads of departments;

- Interviewing heads of departments on personnel management issues, implementation of personnel work;

- Method of "360 degrees", when an employee is evaluated from all sides by subordinates, colleagues, managers, clients;

- Grouping system - a method in which all employees are divided into groups depending on the contribution to the workforce activity;

- Group discussion - a method in which an employee enters into a discussion with managers or experts on the results of his work or prospects;

- Matrix method, when the qualities of a particular employee are compared with characteristics that are ideal for the position held;

- The arbitrary characteristics system method, when the management or personnel service highlights the brightest achievements and the worst mistakes in a person's work, and by comparing them, draws conclusions $[19,20]$.

The decisions made by the results of personnel assessment, are aimed at:

- changes in the size of the compensation package, in particular, wages and incentives (punishment);

- alignment of human resources with the development plans of the company by informing employees on the goals of their activities, career development and personal development [21];

- assessment of the current situation of the organization and identification of business issues. 


\section{Results}

We distinguish the following stages in the process of personnel assessment:

Stage 1 -the preparatory stage. At this stage, a resolution for assessment is being prepared, a CertificationCommission is approved, documentation is being prepared, theworkforce is informed on the deadlines and certification procedure;

Stage 2 - the main stage. The work of the Commission is organized by divisions of the organization, the individual contribution of employees is assessed, questionnaires are filled in, and computer processing of results is carried out.

Stage 3 - the final stage. The results of the assessment are summed up; personal decisions are made related to the promotion of employees, referral to study, relocation or dismissal of employees who have not passed a certification.

As a rule, there is a need to involve external experts - professional consultants from outside during certification. In modern conditions, there occur very common situations, when the basic conditions are set by a client, which is a commercial organization, whereasthe organization of certification system is set up directly by the consultants [22, 23].

Consultants may also be involved as subject matter experts. They can suggest ways to solve one or another task arising in the framework of the assessment procedure and assist in the training of personnel in the construction and implementation of the certification system. External consultants can also be invited to solve individual problems during certification. For example, you can involve an expert to organize and conduct professional testing of employees, an assessment of key employees, interviews with the heads of departments on personnel management, personnel work, and others [24].

The schedule of the assessment procedure shall be transferred to the employees of the organization at least one month prior toits commencement. At least two weeks prior to the assessment, the Commission shall submit a Reference Letter and an Assessment sheet [25].

The Assessment sheet contains objective information on the employee in respect of the work experience in the organization by the specialty, education, the position held, etc.

The Reference Letter contains information on the generalized results of the assessment of the employee's activity, information from the questionnaire survey describing the employee's behavior in the team, and the manager's opinion of the employee.

The CertificationCommission reviews the submitted documents, the information on the employee, the results of his activity, the results of the current assessment.

The decision of the Commission is delivered to the employee. The Commission points out the strengths and weak sides of his work, makes recommendations for his professional growth or for advanced training.

Following the results of the meeting the Certification Commission draws up a protocol. Certification materials are provided to the Head of the organization for making further decision.

The results of the assessmentare discussed at the production meetings of the workforce with the participation of the trade union organization.

In order to increase the assessment effectiveness, its results must be approved in a Resolution. In particular, decisions shall be made on personnel changes, on encouraging positively certified employees, on including prospective employees in the reserve for promotion.

The frequency of assessment is fixed in the Regulations on the assessment. As a rule, it is carried out once in every 3-5 years. In some cases, you can hold extraordinary or early certification of an employee.

Thus, the effectiveness of the personnel assessment system is significantly influenced by well-thought-out and clearly defined requirements that are associated with the 
implementation of individual stages of the certification process, ensuring objectivity in assessment of the activities of employees, and observing the conditions for full implementation of the Certification Commission recommendations.

Currently, there are certain weak points in the personnel assessment system in most of the agricultural enterprises of the Republic of Tatarstan.

First, a biased assessment of the certified employees'activity on the part of theCertification Commission members. Some managers, being the members of the commission, prefer to avoid pointing out directly to employees their low indicators of work or mistakes made by them, thus, trying to escape open confrontation with subordinates. As a consequence, the results of staff activities are given a biased and vague assessment. It leads to a decrease in staff confidence in certification as a system on the whole capable of fair assessment of their achievements in work.

Second, not all managers are psychologically ready to objectively assess the work of the personnel, since negative certification results cause a demotion, deprivation of bonuses, and dismissal of employees after certification.

Third, due to low awareness, department heads fail to use the entire results of the assessment.

Fourth, the enterprise lacks unified forms of working documentation for personnel assessment and certification.

Fifth, enterprise managers often considerthe assessment as an additional burden, which distracts employees from performing of their basic duties.

Thus, there is an objective demandin an effective certification system development, meeting the goals of the organization under study, its needs and the corporate culture that has been developed in it.

Before making a decision in terms of the certification, it is necessary to assess the potential of the personnel at an enterprise. Such assessment allows to study the experience and qualification level of the personnel (Table 1).

Table 1. "Pravda" LLC staff composition analysis.

\begin{tabular}{|l|l|l|l|}
\hline Position & 2015 & 2016 & 2017 \\
\hline Managers & 4 & 4 & 4 \\
\hline Specialists & 13 & 15 & 18 \\
\hline Sales staff & 6 & 5 & 5 \\
\hline Supporting staff & 4 & 8 & 11 \\
\hline Permanent workers & 67 & 67 & 68 \\
\hline Seasonal and temporary workers & 16 & 16 & 17 \\
\hline Total: & 110 & 115 & 123 \\
\hline
\end{tabular}

Analyzing the dynamics of the number of personnel, we can say that there is an increase in all its categories. The number of managers has not changed from 2015 to 2017. The number of specialists is increased by $38,5 \%$, which occurred due to the increasing complexity of managerial tasks and the additional assignments caused by the increase in the trading capacities of the enterprise. The number of support personnel increased by 2.7 times. This is explained by the fact that the activity expansion and an increasing staff number in general requires a larger number of the maintenance personnel.

The division of the enterprise personnel by the level of education is presented in Table 2 . 
Table 2. The division of the "Pravda" LLC enterprise staff by the level of education.

\begin{tabular}{|l|l|l|l|}
\hline Designation & 2015 & 2016 & 2017 \\
\hline Higher Vocational education & 69 & 70 & 70 \\
\hline Secondary Vocational education & 40 & 43 & 51 \\
\hline Apprentices & 1 & 2 & 2 \\
\hline Total: & 110 & 115 & 123 \\
\hline
\end{tabular}

Based on the data presented, it should be noted that more than half of all employees in Pravda LLC possess higher vocational education. From the beginning of 2015 to 2017, the number of employees with the higher education has increased by $1,44 \%$. At the same time, the number of employees with the secondary vocational education has increased by $27,5 \%$. This suggests that the labor market requires high qualification from its potential employees, as well as deep knowledge in the field of their professional activities.

On the basis of the analysis and taking into account the information provided by the HR department, the Director makes a decision on holding the assessment.

\section{Discussion}

The main objectives of the assessment at an agricultural enterprise are:

- transmitting common corporate goals, standards and values;

- assessment of the staff competence compliance with the objectives and requirements of the enterprise;

- rational use of human resources;

- increase of the responsibility and efficiency among the staff;

- strengthening corporate culture.

For achievement of these goals it is necessary to solve the following tasks:

- determine the quantitative and qualitative performance of employees;

- assess the compliance of employees with their positions;

- assess the level of competencies development;

- set goals and objectives of staff activities for the upcoming period;

- develop a program of activities related to staff development;

- establish the relationship of documents regulating labor remuneration with the results of certification;

- create a list of personnel reserve.

As already noted, personnel certification should be carried out in three stages.

At the first preparatory stage, the agricultural organization develops certification plans; selects methods and standard forms of employees' assessment; prepares internal instructions for members of the certification commission; makes a list of employees, who are subject to certification, prepare a certification schedule; notify employees on the timing of certification; prepare the letterheads and standard forms necessary for certification.

The HR department on the basis of the Resolution issued by the Headmanager, prepares an order for certification, which contains information on the timing of certification, the schedule for certification in structural units. The schedule and deadlines for certification are approved by the Director of the agricultural enterprise, and this information is delivered to the staff one month before the start of the assessment procedure.

The Director of the enterprise appoints the Certification Commission, which consists of the Head of the personnel service (Chairman), the Head of the department, which is subject to the certification (member), lawyer (member), psychologist - invited expert (member). 
All employees who are subject to certification are informed about its implementation. In addition, they receive the necessary set of documents.

At the second stage the certification is carried out. The Certification Commission established at the agricultural enterprise examines the performance of each employee, prepares the necessary documents, enters the received information into an electronic database and analyzes it.

"A Pattern of Competences for Managers, Specialists and Workers" is formed for each employee of the enterprise and filled in the "Assessment Form for Managers, Specialists, Employees by Competences", which records information on its performance, qualifications, professional experience, strong and weak points, the opportunity to be transferred to a more responsible and challenging work.

Preliminary assessment form is filled in by the certified employee, then it is filled by the immediate supervisor, and transferred to the Certification Commission.

As an example, we have developed the "A Pattern of Competences for Managers, Specialists and Employees of the Enterprise" (Table 3) and "The Form for assessment of managers, specialists and employees of the enterprise by their competences" for the position of a Chief Agronomist (Table 4).

Table 3. A Pattern of Competences for Managers, Specialists and Employees of the Enterprise.

\begin{tabular}{|c|l|}
\hline $\begin{array}{l}\text { Structural } \\
\text { subdivision }\end{array}$ & Agronomical service \\
\hline Position & Chief Agronomist \\
\hline Competence & \multicolumn{1}{|c|}{ Professional competences } \\
\hline \multicolumn{2}{|c|}{ Competence description } \\
\hline $\begin{array}{c}\text { 1. In the field of } \\
\text { agricultural } \\
\text { technology of } \\
\text { varying intensity } \\
\text { realization }\end{array}$ & $\begin{array}{l}\text { Possess the following skills: } \\
\text { - handling for planted and sown agricultural crops; } \\
\text { - preparation of sowing and planting materials; } \\
\text { - - organization of activity for sowing field crops; } \\
\text { - development of calendar schedules for sowing and handling for } \\
\text { crops; } \\
\text { - monitoring the work on collection of the harvested crops and their } \\
\text { transportation to the storage; } \\
\text { - development and introduction of technologies for the control of } \\
\text { pests and plant diseases; } \\
\text { - choice of agricultural technologies for various crops; } \\
\text { - determining quality of crop products. }\end{array}$ \\
$\begin{array}{c}\text { 2. In the field of } \\
\text { soil productivity } \\
\text { reproduction and } \\
\text { their protection } \\
\text { from deflation } \\
\text { and erosion }\end{array}$ & $\begin{array}{l}\text { Possess the following skills: } \\
\text { - increasingsoil productivity; } \\
\text { - holding agro-technical activities for soil protection from deflation } \\
\text { and erosion; } \\
\text { - meliorative systems condition monitoring. }\end{array}$ \\
\hline $\begin{array}{c}\text { 3. In the field of } \\
\text { storage, } \\
\text { transportation, } \\
\text { presale } \\
\text { preparation and } \\
\text { realization of crop } \\
\text { products }\end{array}$ & $\begin{array}{l}\text { Possess the following skills: } \\
\text { - selecting methods and techniques of crop products placement for } \\
\text { storage; } \\
\text { - preparation of facilities for crop products storage for operation; } \\
\text { - organizing and fulfillment of crop products preparation } \\
\text { realization and transportation. }\end{array}$ \\
\hline
\end{tabular}




\begin{tabular}{|c|c|}
\hline $\begin{array}{l}\text { 4. In the field of } \\
\text { production and } \\
\text { technological } \\
\text { activity }\end{array}$ & $\begin{array}{l}\text { Possess the following skills: } \\
\text { - completing a set of tillage, sowing and harvesting facilities, } \\
\text { maintaining technological adjustments of agricultural machines; } \\
\text { - determining the proportions, methods and technology of fertilizer } \\
\text { application for agricultural crops; } \\
\text { - substantiating the system of crop rotation and land management in } \\
\text { the agricultural organization; } \\
\text { - substantiating the technology of sowing crops and handling of them; } \\
\text { - substantiating methods of harvesting crops, primary processing of } \\
\text { crop products and placing it for storage; } \\
\text { - substantiating the technology for improving and rational use of } \\
\text { natural forage lands, preparation of coarse and succulent fodder; } \\
\text { - ensuring labor safety in the production of crop products. }\end{array}$ \\
\hline $\begin{array}{l}\text { 5. In the field of } \\
\text { agricultural } \\
\text { production } \\
\text { digitalization }\end{array}$ & $\begin{array}{l}\text { Possess the following skills: } \\
\text { - applying digital methods, technologies, technical means for fields } \\
\text { monitoring, } \\
\text { collect digital data on plants, animals and useful microorganisms, } \\
\text { digital methods for compiling and updating soil maps, methods for } \\
\text { updating and using selection and genetic material; } \\
\text { - introducing digital tools for the use of information resources, } \\
\text { platforms and technologies on agricultural facilities for increasing the } \\
\text { efficiency of agricultural production. }\end{array}$ \\
\hline \multicolumn{2}{|r|}{ Management competences } \\
\hline $\begin{array}{l}\text { 6. In the field of } \\
\text { the activities of } \\
\text { crop production } \\
\text { management }\end{array}$ & $\begin{array}{l}\text { Possess the following skills: } \\
\text { - planning of the main indicators of crop production; } \\
\text { - planning the performance of work by the employees; } \\
\text { - organizing of the workforce activity; } \\
\text { - monitoring the progress and assessment of the work performance by } \\
\text { the employees; } \\
\text { - maintaining the approved accounting and reporting documentation. }\end{array}$ \\
\hline $\begin{array}{l}\text { 7. In the field of } \\
\text { organization and } \\
\text { management } \\
\text { activity }\end{array}$ & $\begin{array}{l}\text { Possess the following skills: } \\
\text { - analysing technological process as an object of monitoring; } \\
\text { - determine the cost estimate of the main production resources of an } \\
\text { agricultural enterprise; } \\
\text { - organizing the work performance by the employees, finding and } \\
\text { making management decisions in the field of organizing and setting } \\
\text { standards for work in different economic conditions; } \\
\text { - preparing scientific documentation and production reports. }\end{array}$ \\
\hline
\end{tabular}

By reasonable and correct application of the competence pattern, it is possible to solve certain tasks in the field of personnel management, achieve strategic goals and increase the competitiveness of an enterprise. In particular, as a result, the applicants whose skills and knowledge do not comply with the competencies in this profile shall be dismissed. The assessment reveals the most talented and promising employees who can ensure the future success of the enterprise. Based on the competency pattern, a team and personnel reserve shall be formed, when the enterprise plans to reach a new level of development; the company can more effectively address the issues of developing a system for training and motivating personnel. 
Table 4. The Form for assessment of managers, specialists and employees of the enterprise by their competences (fragment).

\begin{tabular}{|c|c|c|c|c|}
\hline $\begin{array}{l}\text { Employee: Sidorov Ivan Petrovich } \\
\text { Profession: Chief Agronomist } \\
\text { Head: Fedorov Igor Mikhailovich } \\
\text { Assessment reason: } \\
\text { 1. Planned } \\
\text { 2. Merits } \\
\text { 3. Unfavorable performance of duties } \\
\text { 4. Termination of probation period } \\
\text { 5. Promotion } \\
\text { 6. Other_ Entry into o } \\
\text { Last assessment date } 10 / 11 / 2013 \text { Current asses }\end{array}$ & w date:Nove & ber 15,2018 & & \\
\hline \multirow[t]{2}{*}{ Criteria of competences assessment } & \multicolumn{4}{|c|}{ Competence level } \\
\hline & $\begin{array}{l}\text { Lack of } \\
\text { competen } \\
\text { ce level }\end{array}$ & $\begin{array}{l}\text { Developm } \\
\text { ent level }\end{array}$ & $\begin{array}{l}\text { Experienc } \\
\text { e level }\end{array}$ & $\begin{array}{l}\text { Skill } \\
\text { level }\end{array}$ \\
\hline $\begin{array}{l}\text { 1. Skills of determination agro-landscape } \\
\text { conditions compliance with the agricultural } \\
\text { crops growing requirements under their } \\
\text { placement along the territory of the land use }\end{array}$ & & & + & \\
\hline $\begin{array}{l}\text { 2. Skills of substantiation the agricultural crop } \\
\text { types selection considering the peculiarities of } \\
\text { regional conditions and land use } \\
\text { intensification level }\end{array}$ & & + & & \\
\hline \multicolumn{5}{|l|}{ 3. Skills of the seeds preparation to sowing } \\
\hline $\begin{array}{l}\text { 4. Skills of the energy and resource-saving } \\
\text { ecologically clean technology application for } \\
\text { production }\end{array}$ & & + & & \\
\hline $\begin{array}{l}\text { 5. Skills of mineral and organic fertilizers } \\
\text { dosage calculation, skills of preparation and } \\
\text { application of fertilizers for agricultural crops }\end{array}$ & & & + & \\
\hline 6. Skills of crop rotation system organization & & & + & \\
\hline $\begin{array}{l}\text { 7. Skills of soil cultivation system in crop } \\
\text { rotation adapting }\end{array}$ & & & + & \\
\hline $\begin{array}{l}\text { 8. Skills of agricultural crops sowing } \\
\text { organization and their handling }\end{array}$ & & & + & \\
\hline $\begin{array}{l}\text { 9. Skills of verification the system of plants } \\
\text { protection from harmful organisms and } \\
\text { unfavorable weather conditions }\end{array}$ & & & + & \\
\hline $\begin{array}{l}\text { 10. Skills of digital methods, technologies, } \\
\text { technical means application for agricultural } \\
\text { crops production }\end{array}$ & & + & & \\
\hline $\begin{array}{l}\text { 11. Skills of harvesting, primary handling of } \\
\text { agricultural products and placing it for storage }\end{array}$ & & & + & \\
\hline $\begin{array}{l}\text { 12. Skills of technology application for the } \\
\text { improvement and efficient use of natural } \\
\text { forage lands, forage preparation }\end{array}$ & & & + & \\
\hline $\begin{array}{l}\text { 13. Skills of the subdivision activity of an } \\
\text { agricultural entity for plants production } \\
\text { organization }\end{array}$ & & + & & \\
\hline
\end{tabular}




\begin{tabular}{|c|c|c|c|c|}
\hline \multicolumn{2}{|c|}{$\begin{array}{l}\text { 14. Skills of making managerial decisions on } \\
\text { realization of growing agricultural crops in } \\
\text { different economic and climatic conditions }\end{array}$} & & + & \\
\hline \multicolumn{2}{|c|}{$\begin{array}{l}\text { 15. Skills of economic efficiency calculation } \\
\text { for technological methods, fertilizers, means } \\
\text { of the plants protection, new varieties } \\
\text { application }\end{array}$} & & + & \\
\hline \multicolumn{2}{|c|}{$\begin{array}{l}\text { 16. Skills of holding marketing research at the } \\
\text { agricultural markets }\end{array}$} & & + & \\
\hline \multicolumn{2}{|c|}{$\begin{array}{l}\text { 17. Skills of crop products quality monitoring } \\
\text { at its storage and realization }\end{array}$} & & + & \\
\hline \multicolumn{2}{|c|}{$\begin{array}{l}\text { 18. Skills of the compliance with } \\
\text { technological and labor discipline monitoring }\end{array}$} & & & \\
\hline \multicolumn{2}{|c|}{$\begin{array}{l}\text { 19. Skills of labor safety in the production } \\
\text { process provision }\end{array}$} & & + & \\
\hline $\begin{array}{l}\text { Strong points of the } \\
\text { candidate }\end{array}$ & \multicolumn{4}{|c|}{$\begin{array}{l}\text { Possesses skills in the field of different intensive technologies } \\
\text { application, soil protection from erosion and deflation, soil } \\
\text { fertility recovery, production and technological activity; in the } \\
\text { field of crops production activity management. }\end{array}$} \\
\hline $\begin{array}{l}\text { Weak points of the } \\
\text { candidate }\end{array}$ & \multicolumn{4}{|c|}{$\begin{array}{l}\text { Professional competences in the field of different intensive } \\
\text { agricultural technology and digital methods application, } \\
\text { technology and technical means for crops production; } \\
\text { managerial competences in the field of organization and } \\
\text { management activity still require further development. }\end{array}$} \\
\hline \multicolumn{4}{|c|}{$\begin{array}{l}\text { Decision made in respect of the candidate: } \\
\text { Send for the re-interviewing } \\
\text { Send for the upgrading (professional qualification upgrading) }\end{array}$} & \\
\hline \multicolumn{5}{|c|}{ Interview held on: November 15, 2018} \\
\hline
\end{tabular}

The submitted list of competencies serves a source for quantitative assessment of the certified person in terms of his conformity to the position by each item of the requirements. It is recommended to apply the following rating scale:

- level of incompetence ( 1 point). The certified employee clearly does not meet the requirements of the position. Weakly expressed competence is not compensated by other competencies or accessible forms of training;

- Level of development ( 2 points). Certified employee does not meet the requirements of the position in terms of the certain competencies. This discrepancy can be compensated by the development of weak competencies and high rates for other competencies;

- Level of experience ( 3 points). The certified employee fully meets the requirements of the position;

- Skill level (4 points). The professional level of the certified employee is higher than the requirements for a specific competence.

If any competence item of the assessed employee is determined at the "level of incompetence", then this candidate cannot be considered as recommended for the position. An exception may be due to the situation, when a properly conducted long search does not reveal an alternative. In this case, you can adjust the requirements for the position.

If for a number of competencies, the assessed employee is determined at the "level of skill", then it is necessary to analyze the motives that could hold him in the position, creating an interest in the work. 
As a rule, the competencies by which the certified employee is assessed must be at the "experience level".

At the third stage, the results of the assessment are summarized, the materials provided are reviewed, thereport of the certified person about his work is heard. In assessing the work of the assessed person, his personal contribution to the implementation of the plans of the department, his qualifications, and the performance of his official duties are taken into account.

Based on these data, the Certification Commission certifies the activities of the employee by holding an open vote. In this case, the following assessment options are possible: compliance with the position held; compliance with the position under certain conditions (improvement of work with the recommendations of the commission, recertification a year later); not matching the position held.

The results of certification are recorded in a protocol. The decisions of the Certification Commission are approved by the Director of the agricultural enterprise.

All documents on personnel assessment are transferred to the HR department of the enterprise. HR department forms the "Individual development plan for managers, specialists, employees of the enterprise" for each employee, who has passed certification (Table 5).

Table 5. Individual career map for managers, specialists and employees of the enterprise.

\begin{tabular}{|c|c|c|c|c|c|}
\hline \multicolumn{2}{|c|}{ Name of the employee } & \multicolumn{4}{|c|}{ Sidorov Ivan Petrovich } \\
\hline \multicolumn{2}{|c|}{ Position } & \multicolumn{4}{|c|}{ Chief Agronomist } \\
\hline \multicolumn{2}{|c|}{ Subdivision } & \multicolumn{4}{|l|}{ Agronomy service } \\
\hline \multicolumn{2}{|c|}{$\begin{array}{l}\text { Qualities and professional skills, } \\
\text { which requiredevelopment }\end{array}$} & \multicolumn{4}{|c|}{$\begin{array}{l}\text { Professional competences in the field of different intensive } \\
\text { agro- technology } \\
\text { Managerial competences in the field of organization and } \\
\text { management activity }\end{array}$} \\
\hline \multicolumn{2}{|c|}{ Development goals } & \multicolumn{4}{|c|}{$\begin{array}{l}\text { Improvement and development of professional and } \\
\text { managerial competences for professional growth and labor } \\
\text { productivity increase }\end{array}$} \\
\hline $\begin{array}{l}\text { Development } \\
\text { lines }\end{array}$ & $\begin{array}{l}\text { Development } \\
\text { activities }\end{array}$ & $\begin{array}{l}\text { Necessary } \\
\text { support }\end{array}$ & $\begin{array}{l}\text { Deadline } \\
\text { for control }\end{array}$ & $\begin{array}{l}\text { Control } \\
\text { method }\end{array}$ & $\begin{array}{l}\text { Fulfillmen } \\
\mathrm{t} \text { mark }\end{array}$ \\
\hline $\begin{array}{l}\text { 1. Activity } \\
\text { organization on } \\
\text { growing high } \\
\text { quality branded } \\
\text { seeds and } \\
\text { planting } \\
\text { material, seed } \\
\text { bank } \\
\text { establishment }\end{array}$ & $\begin{array}{l}\text { Independent } \\
\text { preparation } \\
\text { New } \\
\text { technology } \\
\text { study } \\
\text { Benchmarking }\end{array}$ & $\begin{array}{l}\text { Discussion with } \\
\text { top authorities } \\
\text { Visit to the } \\
\text { leading enterprise }\end{array}$ & $\begin{array}{l}\text { Once in } \\
\text { half year }\end{array}$ & $\begin{array}{l}\text { Project } \\
\text { submitting }\end{array}$ & $\begin{array}{l}\text { Innovative } \\
\text { technology } \\
\text { and front- } \\
\text { line } \\
\text { experience } \\
\text { studied }\end{array}$ \\
\hline $\begin{array}{l}\text { 2. Application } \\
\text { of energy- } \\
\text { saving } \\
\text { technology for } \\
\text { biologically } \\
\text { pure } \\
\text { agricultural } \\
\text { production }\end{array}$ & $\begin{array}{l}\text { Intramural } \\
\text { training } \\
\text { followed by } \\
\text { examination }\end{array}$ & $\begin{array}{l}\text { Sending to study } \\
\text { Visit to the } \\
\text { leading enterprise }\end{array}$ & $\begin{array}{l}\text { At the end } \\
\text { of the year }\end{array}$ & $\begin{array}{l}\text { Examinatio } \\
\mathrm{n}\end{array}$ & $\begin{array}{l}\text { Awarded } \\
\text { a Diploma } \\
\text { of } \\
\text { upgrading, } \\
\text { leading } \\
\text { enterprise } \\
\text { studied }\end{array}$ \\
\hline $\begin{array}{l}\text { 3. Information } \\
\text { resources } \\
\text { application, } \\
\text { platforms and }\end{array}$ & \begin{tabular}{lr}
\multicolumn{2}{l}{ Participation } \\
in & seminars \\
and & round \\
tables &
\end{tabular} & $\begin{array}{l}\text { Intramural } \\
\text { participation }\end{array}$ & $\begin{array}{l}\text { At the end } \\
\text { of the year }\end{array}$ & $\begin{array}{l}\text { Set of } \\
\text { documents } \\
\text { submitting }\end{array}$ & $\begin{array}{l}\text { Gained } \\
\text { skills of } \\
\text { digital } \\
\text { methods }\end{array}$ \\
\hline
\end{tabular}




\begin{tabular}{|c|c|c|c|c|c|}
\hline $\begin{array}{l}\text { at agricultural } \\
\text { entities } \\
\text { increasing the } \\
\text { efficiency of } \\
\text { agricultural } \\
\text { production }\end{array}$ & & & & & $\begin{array}{l}\text { applicatio } \\
\mathrm{n} \text {, } \\
\text { technologi } \\
\text { es and } \\
\text { technical } \\
\text { means }\end{array}$ \\
\hline $\begin{array}{l}4 . \\
\text { Development } \\
\text { of personal } \\
\text { leadership } \\
\text { potential and } \\
\text { skills of the } \\
\text { effective team } \\
\text { building }\end{array}$ & $\begin{array}{l}\text { Trainings and } \\
\text { seminars }\end{array}$ & $\begin{array}{l}\text { Regular meetings } \\
\text { with the specialist } \\
\text { on HR } \\
\text { management } \\
\text { Reading of } \\
\text { special literature }\end{array}$ & $\begin{array}{l}\text { During the } \\
\text { year }\end{array}$ & Testing & $\begin{array}{l}\text { Gained } \\
\text { skills of } \\
\text { the } \\
\text { effective } \\
\text { team } \\
\text { building }\end{array}$ \\
\hline $\begin{array}{l}\text { 5. Organization } \\
\text { of the } \\
\text { employees } \\
\text { activity, } \\
\text { finding and } \\
\text { making } \\
\text { managerial } \\
\text { decisions in the } \\
\text { field of } \\
\text { organization } \\
\text { and } \\
\text { standardization } \\
\text { of labor in } \\
\text { different } \\
\text { economic } \\
\text { conditions }\end{array}$ & $\begin{array}{l}\text { Topical } \\
\text { master classes } \\
\text { Fulfillment of } \\
\text { special tasks } \\
\text { (projects) }\end{array}$ & $\begin{array}{l}\text { Internal trainings } \\
\text { Independent } \\
\text { preparation }\end{array}$ & $\begin{array}{l}\text { During the } \\
\text { year }\end{array}$ & $\begin{array}{l}\text { Business } \\
\text { game }\end{array}$ & $\begin{array}{l}\text { Studied } \\
\text { innovative } \\
\text { methods } \\
\text { of the } \\
\text { agricultur } \\
\text { al entity } \\
\text { subdivisio } \\
\mathrm{n} \text { activity } \\
\text { organizati } \\
\text { on on } \\
\text { agricultur } \\
\text { al and } \\
\text { plant } \\
\text { growing } \\
\text { products } \\
\text { manufactu } \\
\text { ring }\end{array}$ \\
\hline
\end{tabular}

"Individual Career Map" application allows the company solving the following tasks:

- promote targeted and systematic staff development;

- coordinate the goals of the enterprise and the goals of staff development;

- analyze the strong and weak points of employees;

- ensure the implementation of control measures.

Employees of the enterprise on the basis of the "Individual Career Map" can timely prepare for participation in new projects, enter into a new position; highlight points worth their attention during development and training period.

The system of personnel performance assessment must meet the goals, objectives, needs and organizational culture of an agricultural enterprise. Therefore, improving the efficiency of staff, as the most important priority of the organization, is the main incentive for the development and implementation of a new system of employees' certification.

\section{Conclusions}

Thus, personnel assessment is an essential tool contributing to the efficient operation of an enterprise. It helps in solving a whole range of tasks associated with improving the effectiveness of the human capital application.

Personnel assessment is a legal basis for transferring, promotion up the career ladder, rewarding, determining salaries, demotion or dismissal. In modern conditions, certification contributes to the quality improvement in the composition of the company's employees, 
helps to determine the degree of an employee's workload and using each person in compliance with his specialty, to improve methods and style of personnel management. The assessment results in finding the reserves of professional growth, increase of labor productivity of workers, creation of conditions for the optimal use of social guarantees and economic incentives for a more dynamic and comprehensive personality development.

Personnel assessment is a mandatory element of a well-balanced personnel service operating in the personnel management system of any modern enterprise. It guarantees its competitiveness and financial stability in the market, it marks a sign of the management quality as the most important factor for success in competition. Properly built certification system is the first sign of a high level and quality of personnel activity in the organization.

\section{References}

1. A.Y. Sokolov, L.B. Sungatullina, Asian Social Scienc 11(11), 379-384 (2015) DOI: 10.5539 / ass.v11n $11 \mathrm{p} 379$

2. A.M. Abubakar, H. Elrehail, M.A. Alatailat, A. Elçi, Journal of Innovation \& Knowledge 4(2), 104-114 (2019) doi.org/10.1016/j.jik.2017.07.003

3. D.B. Bryan, Advances in Accounting 36, 11-26 doi.org/10.1016/j.adiac.2016.09.005

4. E.A. Antipova, T.I. Alyunova, G.L. Belov, L.G. Vasilyeva, I.P. Nikolaev, A.N. Nikolaeva, T.N. Kokotkina, E.I. Tsaregorodtsev, The Social Sciences 11, 1641-1646 (2016) DOI: 10.3923/sscience.2016.1641.1646

5. B. Denkena, M.-A. Dittrich, F. Winter, Procedia CIRP 63, 265-270 (2017) doi.org/10.1016/j.procir.2017.03.114

6. R.A. Dolzhenko, V.S. Polovinko, S.V. Lobova, Research Journal of Applied Sciences 10, 193-202 (2015) DOI: 10.3923 / rjasci.2015.193.202

7. G.S. Klychova, E.N. Fakhretdinova, A.S. Klychova, N.V. Antonova, Asian Social Science 11(11), 318-322 (2015) DOI: 10.5539 / ass.v11n11p318

8. E. Kalugina, S. Shvydun, Procedia Computer Science 31, 1102-1106 (2014) doi.org/10.1016/j.procs.2014.05.365

9. Dz. Faizrakhmanov, A. Zakirova, G. Klychova, A. Yusupova, A. Klychova, E3S Web of Conferences 91, 06004 (2019) doi.org/10.1051/e3sconf/20199106004

10. L. Topliceanu, L. Bibire, D. Nistor, Procedia - Social and Behavioral Sciences 180, 1030-10375 (2015) doi.org/10.1016/j.sbspro.2015.02.198

11. K. Widjajanti, W. Improving, International Business Management 10, 1599-1609 (2016) DOI: 10.3923 / ibm.2016.1599.1609

12. G. Klychova, A. Zakirova, E. Sadrieva, F. Avkhadiev, A. Klychova, E3S Web of Conferences 91, 06002 (2019) doi.org/10.1051/e3sconf/20199106002

13. H. Laverde-Rojas, M. Gaitan-Angulo, J.-P. Lis-Gutierrez, A. Viloria, P. Vega-Riano, Journal of Engineering and Applied Sciences 12, 2966-2971 (2017) DOI: 10.3923 / jeasci.2017.2966.2971

14. Li-Jen He, International Business Management 9, 1686-1697 (2015) DOI: 10.3923/ibm.2015.1686.1697

15. G.S. Klychova, A.R. Zakirova, K.Z. Mukhamedzyanov, E.R. Sadrieva, A.S. Klychova, Journal of Engineering and Applied Sciences 12(19), 4966-4973 (2017) DOI: 10.3923 / jeasci.2017.4966.4973 
16. Sh. Haneda, K. Ito, Research Policy 47(1), 194-208 (2018) doi.org/10.1016/j.respol.2017.10.008

17. G.S. Klychova, A.R. Zakirova, E.R. Kamilova, International Business Management 10, 5254 (2016) DOI: 10.3923 / ibm.2016.5254.5260

18. M. Fareed, M. Faizal Mohd Isa, W.S. Wan Mohd Noor, International Business Management 10, 1720-1728 (2016) DOI: 10.3923 / ibm.2016.1720.1728

19. N. Abishov, Zh. Kydyrova, G. Urazbaeva, A. Abishova, D. Asan, Procedia - Social and Behavioral Sciences 143, 445-449 (2014) doi.org/10.1016/j.sbspro.2014.07.515

20. A. Zakirova, G. Klychova, A. Yusupova, V. Kirillova, I. Gimadiev, E3S Web of Conferences 91, 06003 (2019) doi.org/10.1051/e3sconf/20199106003

21. L.G. Nabieva, L.M. Davletshina, A.D. Khairullina, E.N. Kulik, International Business Management 10, 5599-5602 (2016) DOI: 10.3923 / ibm.2016.5599.5602

22. G.S. Klychova, B.G. Ziganshin, A.R. Zakirova, G.R. Valieva, A.S. Klychova, Journal of Engineering and Applied Sciences 12, 4958-4965 (2017) DOI: 10,3923 / jeasci.2017.4958.4965

23. M. Mohammed, D. Mébarek, B.Wafa, Ch. Makhlouf, Safety and Health at Work 7(4), 299-306 2016 doi.org/10.1016/j.shaw.2016.04.007

24. A.S. Mukhina, Asian Social Scienc. 11(8), 58-64 (2015) DOI: 10.5539 / ass.v11n8p58

25. E.E. Kausel, S.S. Culbertson, H.P. Madrid, Organizational Behavior and Human Decision Processes 137, 27-44 (2016) doi.org/10.1016/j.obhdp.2016.07.005 